\title{
Relationship of intestinal histology with the resistance to Trichostrongylus colubriformis infection in three breeds of sheep ${ }^{1}$
}

INDEX TERMS: Sheep, Trichostrongylus colubriformis, resistance, mast cells, eosinophils.

RESUMO.- [Associação entre a resposta celular no intestino e a resistência à infecção por Trichostrongylus colubriformis em três raças de ovinos.] Avaliaram-se a associação entre o número de células inflamatórias no intestino delgado e a resistência à infecção por Trichostrongylus colubriformis em ovinos de três raças (Santa Inês, Suffolk e lle de France), naturalmente infectados. Mastócitos, eosinófilos e leucócitos globulares foram quantificados na mucosa intestinal. A concentração de histamina foi estimada em amostras teciduais do intestino, bem como foi determinado o comprimento de machos e fêmeas de $T$. colubriformis. A resposta celular foi similar na mucosa intestinal das três raças ovinas $(P>0,05)$. Houve grande variação entre os ovinos em relação aos resultados parasitológicos e celulares, mesmo nos animais de mesma raça. Em geral, os animais que apresentaram número menor de células inflamatórias tiveram cargas parasitárias maiores, contagens de ovos por grama de fezes mais altas e exemplares de T. colubriformis maiores. Os resultados indica-

\footnotetext{
${ }^{1}$ Received on April 19, 2006.

Accepted for publication on October 2, 2006.

2 Depto Parasitologia, Instituto de Biociências, Universidade Estadual Paulista (Unesp), Caixa Postal 510, Botucatu, SP 18618-000, Brazil. *Corresponding author: amarante@ibb.unesp.br
}

ram que mastócitos, eosinófilos e leucócitos globulares prejudicaram o estabelecimento, o desenvolvimento e a sobrevivência dos parasitas.

TERMOS DE INDEXAÇÃO: Ovinos, Trichostrongylus colubriformis, resistência, mastócitos, eosinófilos.

\section{INTRODUCTION}

The ability of sheep to acquire immunity and express resistance to gastrointestinal nematode infection varies substantially among and within breeds, and is under genetic control (Stear \& Murray 1994). The elucidation of the mechanism that controls such genetic variations in resistance to nematode parasites is critical to design an effective parasite vaccine, and to develop methods to identify geneticallyresistant breeding livestock (Gill et al. 2000).

Harrison et al. (1999) showed that sheep that are immune to Trichostrongylus colubriformis had higher antibody and histamine levels as well as greater numbers of mucosal mast cells and globule leucocytes after challenge, compared to naive sheep. These results are evidence for an immediate hypersensitivity reaction in the intestine of immune sheep, from where challenge larvae may be expelled within $2 \mathrm{~h}$ (Harrison et al. 1999). Similarly, Romney sheep immunized against 
Trichostrongylus colubriformis and then allowed to graze on infected pasture had significantly more globule leucocytes, mast cells and eosinophils in gastrointestinal tissue and significantly higher levels of mucous antiparasitic activity than unimmunized sheep (Douch 1989). Winter et al. (1997) reported an increase in mucosal eosinophil and mast cell numbers in Suffolk lambs during the period of the rejection of adult Nematodirus battus, as compared to uninfected control animals.

Dexamethasone treatment abrogated resistance to a trickle challenge infection with $T$. colubriformis and reduced mucosal globule leucocyte and mast cell numbers. After drug treatment cessation, the re-establishment of resistance and adult worm elimination were associated with mucosa repopulation with large numbers of globule leucocytes and high antiparasitic activities in the mucus. Resistance recovery occurred about 4 weeks after dexamethasone treatment withdrawal (Douch et al. 1986).

This study was carried out to evaluate the relationship between intestinal inflammatory cells and resistance to natural T. colubriformis infections in three breeds of sheep raised in the State of São Paulo, Brazil.

\section{MATERIALS AND METHODS}

Details of the experimental design were described by Amarante et al. (2004). Briefly, 16 Santa Ines, 12 Suffolk, and 12 Ile de France lambs were purchased from different farms. Four lambs were acquired in each farm to ensure minimum genetic variability in each breed. As some animals died during the experiment, this paper presents the results for 16 Santa Ines, 11 Suffolk, and for 9 Ile de France sheep.

All lambs were born in July 2000, except for eight Ile de France and four Suffolk lambs born in June, and four Ile de France born in August. The lambs, weaned at 2 months of age, were moved to the University's facilities in September or early October, where they were housed until the beginning of the trial in late October 2000.

On October 24, 2000, lambs were placed in a paddock (0.6 ha) with Coast-cross grass (Cynodon dactylon) and left there for continual grazing until the youngest sheep had completed 12 months of age, in August of the following year.

To expose the animals to uniform nematode infections before the end of the study, all sheep were treated with levamisole phosphate $(10 \mathrm{mg} / \mathrm{kg})$ plus albendazole $(10 \mathrm{mg} / \mathrm{kg})$ on July 3,2001 . On August 14, 2001, the animals were slaughtered for worm identification and counting.

Parasitological techniques. Fecal samples were taken from the rectum of the slaughtered animals. Fecal egg counts (FEC) were determined using a modified McMaster technique, in which each nematode egg counted represented 100 eggs per gram (EPG) of feces. A culture was made separately for each animal to produce infective gastrointestinal nematode larvae. The obtained larvae were killed, stained with Lugol's iodine, and identified according to descriptions of Keith (1953). Based on larval differentiation and FEC, each genus' EPG was calculated for each animal.

The small intestine was removed at necropsy, opened and the contents collected in a container. A $5 \%$ aliquot of the contents was preserved in $5 \%$ formalin. Then, the small intestines were soaked in saline solution at $39^{\circ} \mathrm{C}$ for 6 hours. A $10 \%$ aliquot of the digested material was processed similarly to the contents. All nematodes in the preserved material were counted and identified (Ueno \& Gonçalves 1988).
Length of Trichostrongylus colubriformis. Ten male and ten female $T$. colubriformis specimens obtained from each animal were mounted on a slide and measured using the Qwin Lite 2.5 (Leica Microsystems) image processing and analysis software. It was not possible to determine the length of male and female specimens from one and two Ile de France animals, respectively.

Histology. Tissue samples taken from the duodenum and jejunum, $10 \mathrm{~cm}$ and $110 \mathrm{~cm}$ from pylorus, respectively, were fixed in Bouin. The samples were then dehydrated with alcohol and embedded in paraffin wax. Sections, $3 \mu \mathrm{m}$ thick, were stained with toluidine blue $1 \%$ or haematoxylin and eosin (HE).

Mast cells were counted in sections stained with toluidine blue, while eosinophils and globule leucocytes in sections stained with HE. Cells were counted under a $10 x$ eye piece containing a calibrated graticule and $100 \mathrm{x}$ objective lens viewing a $0.01 \mathrm{~mm}^{2}$ area. Counts were made systematically from the muscularis to the mucosal surface on 30 graticule fields. The counts were expressed as the number of cells per $\mathrm{mm}^{2}$ of mucosa.

Histamine concentration. To estimate histamine concentrations, tissue samples were collected from the same location where histological samples were taken in the duodenum $(10 \mathrm{~cm}$ from pylorum) and in the jejunum $(110 \mathrm{~cm}$ from pylorum). Samples of $0.5 \mathrm{~g}$ from each intestinal site were washed gently in saline solution, sliced, mixed, and placed in a tube with $5 \mathrm{ml}$ of $0.4 \mathrm{~N}$ perchloric acid. Samples were kept at $4^{\circ} \mathrm{C}$ until be processed. The histamine concentration was determined automatically by the fluorometric method (Shore et al. 1959).

Female nematode egg output. Female T. colubriformis egg output per day was calculated for each animal according to the following formula:

\section{T. colubriformis EPG x fecal output / Number of T. colubriformis females}

Five days before slaughter, the total amount of feces each animal eliminated in a $24-h$ period was collected and weighed. On average, Santa Ines, Suffolk, and Ile de France sheep fecal output corresponded, respectively, to $5.30,4.54$ and $4.73 \%$ of their body weight. These percentages were used to estimate, for each breed, each animal's daily fecal output relative to its body weight.

Statistical analysis. The data were analyzed using Minitab Release 11 , by using a one-way analysis of variance. Significant group mean differences were determined by Fisher's Least Significant Difference (Ott 1992). The data relative to FEC, worm burden, and cell counts in the intestinal mucosa were transformed to $\log _{10}$ $(x+1)$. The mean length of the $T$. colubriformis specimens was determined per animal. Statistical significance was considered as $P<0.05$. The association among the untransformed data was determined using Spearman's rank correlation coefficient (Minitab Release 11).

To facilitate interpretation, result figures are expressed as arithmetic means ( \pm standard deviation) of the untransformed values.

\section{RESULTS}

Lamb worm burden results were published previously (Amarante et al. 2004). Briefly, Trichostrongylus colubriformis was the major species found in the sheep's small intestines. Numbers of T. colubriformis were over dispersed in the three breeds, with no statistical difference among group means $(P>0.05)$. Five Santa Ines lambs had from 290 to 900 specimens; eight from 1310 to 5420 ; while the other three had 9360, 10440, and 31300 worms. This last animal was also infected with Moniezia spp. Four Suffolk lambs had 200 to 
1580 T. colubriformis specimens; four 4320 to 7400 ; and the other three had 12460,24050 , and 39580 specimens. Three Ile de France sheep had 20 to 250 T. colubriformis specimens; four 7720 to 9330 ; while the other two had 22730 and 58320 specimens. Trichostrongylus FEC means ranged from 538 EPG in the Santa Ines, to 618 EPG in the Ile de France sheep $(P>0.05)$.

The highest mast cell count mean in duodenal mucosa $\left(318.2 \pm 142.2\right.$ cells $\left./ \mathrm{mm}^{2}\right)$ was recorded in the Suffolk sheep, while the highest in the jejunal mucosa was found in the Santa Ines sheep (302.5 \pm 90.5 cells $\left./ \mathrm{mm}^{2}\right)$ (Fig.1). Globule leucocyte means were lower than mast cell means (Fig.1). The highest globule leucocyte mean occurred in Ile de France sheep duodenum $\left(97.6 \pm 65.8\right.$ cells $\left./ \mathrm{mm}^{2}\right)$. The highest eosinophil
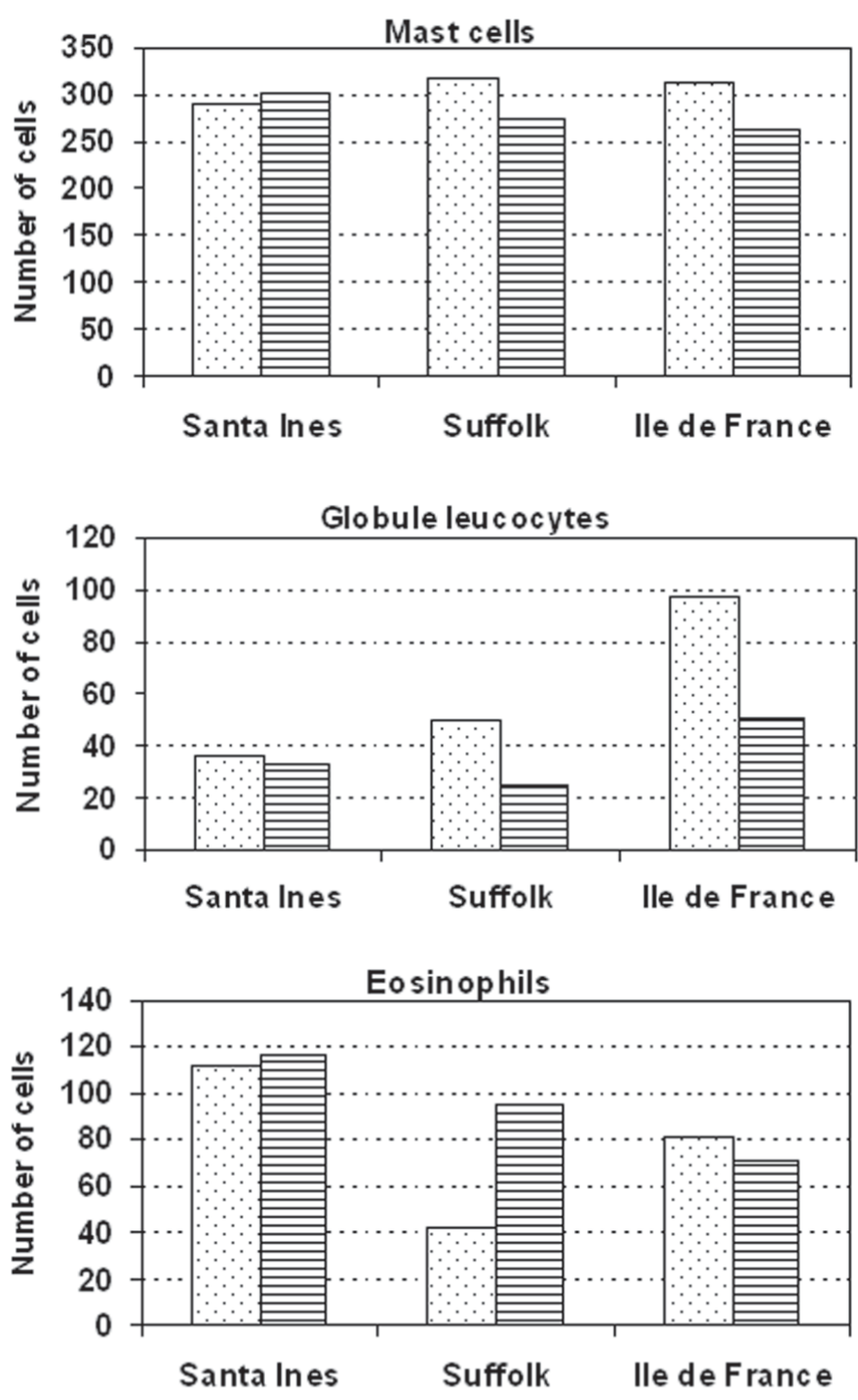

\section{Duodenum 目 Jejunum}

Fig.1. Mean numbers of mast cells, globule leucocytes and eosinophils per $\mathrm{mm}^{2}$ of the duodenal and jejunal mucosa of the Santa Ines, Suffolk and Ile de France sheep, naturally infected with gastrointestinal nematodes. mean (Fig.1) was found in Santa Ines sheep jejunum (116.4 \pm 80.4 cells $/ \mathrm{mm}^{2}$ ). Similar histamine concentrations were found in the three breeds' small intestines (Fig.2). There were no statistical differences among breed means regarding small intestine cell counts and histamine concentrations $(P>0.05)$.

Similar numbers of mast cells, globule leucocytes, and eosinophils were recorded in the duodenum compared to the jejunum $(P>0.05)$. The exception was in Suffolk sheep, which had significantly higher mean globule leucocytes in the duodenum than in jejunum $(P<0.05)$.

The minimum and maximum female length means were, respectively, $5.59 \pm 0.74 \mathrm{~mm}$ (Ile de France group) and $5.75 \pm 0.82 \mathrm{~mm}$ (Santa Ines group), while the minimum and maximum male length means were, respectively, $4.70 \pm$ $0.70 \mathrm{~mm}$ (Ile de France group) and $4.78 \pm 0.49 \mathrm{~mm}$ (Suffolk group) (Fig.3). The minimum daily egg output mean per female was 311.9 eggs (Santa Ines), while the maximum was 390.8 eggs (Ile de France). There were no statistical differences among breed means $(P>0.05)$.

Small intestine histamine concentration correlated significantly with mast cell numbers in the duodenum and jejunum $(P<0.01)$. Most of the overall correlation coefficients

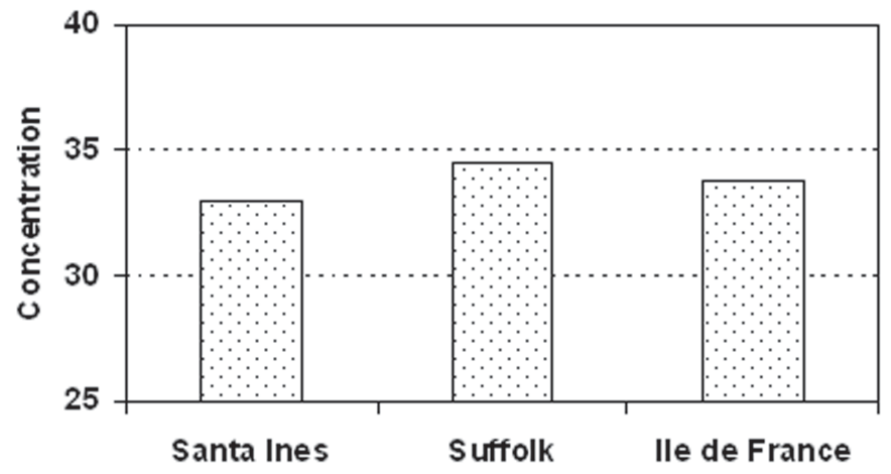

Fig.2. Mean concentration of histamine ( $\mathrm{mg} / \mathrm{g}$ of tissue) in the small intestine of the Santa Ines, Suffolk and Ile de France sheep naturally infected with gastrointestinal nematodes.

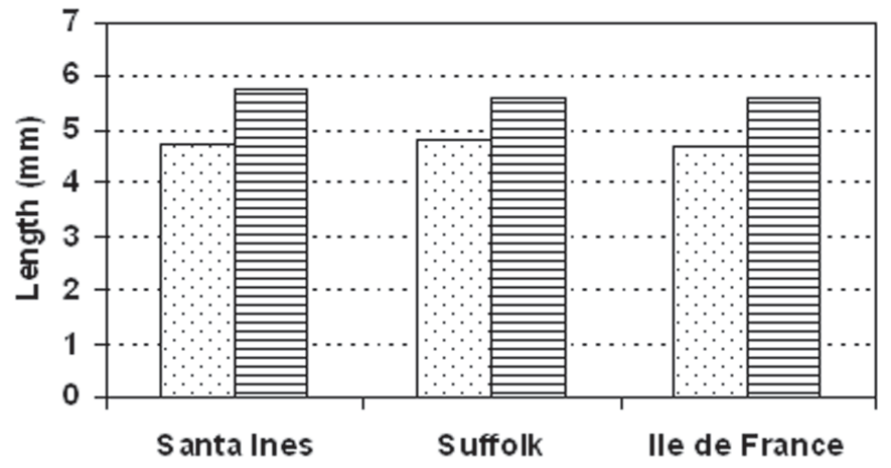

\section{Males 目Females}

Fig.3. Mean lengths (mm) of males and females of Trichostrongylus colubriformis specimens recovered from Santa Ines, Suffolk and Ile de France sheep naturally infected. 
Table 1. Overall relationship ${ }^{\mathrm{a}}$ between histamine concentration and cell counts in the duodenum and jejunum of the Santa Ines, Suffolk and lle de France sheep

\begin{tabular}{|c|c|c|c|c|c|c|}
\hline & $\begin{array}{l}\text { Histamine in } \\
\text { small intestine }\end{array}$ & $\begin{array}{l}\text { Mast cells in } \\
\text { duodenum }\end{array}$ & $\begin{array}{l}\text { Eosinophils } \\
\text { in duodenum }\end{array}$ & $\begin{array}{c}\text { Globule } \\
\text { Leucocytes } \\
\text { in duodenum }\end{array}$ & $\begin{array}{l}\text { Mast cells } \\
\text { in jejunum }\end{array}$ & $\begin{array}{c}\text { Eosinophils } \\
\text { in jejunum }\end{array}$ \\
\hline Mast cells in duodenum & $0.528^{\text {粠 }}$ & & & & & \\
\hline Eosinophils in duodenum & 0.114 & $0.455^{\text {粰 }}$ & & & & \\
\hline Globule leucocytes in duodenum & 0.224 & 0.292 & -0.010 & & & \\
\hline Mast cells in jejunum & $0.542^{\text {䅉 }}$ & $0.666^{\text {粎 }}$ & $0.414^{*}$ & 0.187 & & \\
\hline Eosinophils in jejunum & -0.032 & 0.069 & $0.488^{\text {橉 }}$ & $-0.400^{*}$ & -0.005 & \\
\hline Globule leucocytes in jejunum & $0.342^{*}$ & $0.556^{\text {䊩 }}$ & $0.409^{*}$ & $0.541^{\text {***** }}$ & $0.626^{\text {***** }}$ & -0.147 \\
\hline
\end{tabular}

Table 2. Overall relationship ${ }^{a}$ between parasitological variables of Trichostrongylus colubriformis

\begin{tabular}{|c|c|c|c|c|c|}
\hline & $\begin{array}{c}\text { Total } \\
\text { burden }^{b}\end{array}$ & $\begin{array}{c}\text { Number of } \\
\text { females }\end{array}$ & $\begin{array}{c}\text { Male } \\
\text { length }\end{array}$ & $\begin{array}{l}\text { Female } \\
\text { length }\end{array}$ & FEC $^{\mathrm{C}}$ \\
\hline Number of females & $0.993^{* * * *}$ & & & & \\
\hline Male length & $0.621^{\text {**** }}$ & $0.606^{* * * *}$ & & & \\
\hline Female length & $0.709^{* * * *}$ & $0.696^{* * * * *}$ & $0.805^{\text {*** }}$ & & \\
\hline FEC & $0.685^{* * * *}$ & $0.652^{\text {䄅 }}$ & $0.655^{\text {粠 }}$ & $0.608^{\text {米燐 }}$ & \\
\hline Eggs/female ${ }^{d}$ & -0.068 & -0.083 & 0.303 & 0.334 & 0.195 \\
\hline
\end{tabular}

a Spearman's rank correlation coefficients, b Total T. colubriformis burden, 'Fecal egg counts, ${ }^{d}$ Daily production of eggs per female, ${ }^{* * *} P<0.01$.

Table 3. Overall relationship ${ }^{\mathrm{a}}$ between cellular responses in the intestinal mucosa of the Santa Ines, Suffolk and Ile de France sheep and the parasitological variables of Trichostrongylus colubriformis

\begin{tabular}{|c|c|c|c|c|c|}
\hline & $\begin{array}{l}\text { Worm } \\
\text { burden }\end{array}$ & $\mathrm{FEC}^{\mathrm{b}}$ & $\begin{array}{l}\text { Length of } \\
\text { males }\end{array}$ & $\begin{array}{c}\text { Length of } \\
\text { females }\end{array}$ & Eggs/female ${ }^{c}$ \\
\hline Histamine & -0.164 & -0.300 & -0.177 & -0.047 & 0.209 \\
\hline $\begin{array}{l}\text { Mast cells in } \\
\text { duodenum }\end{array}$ & $-0.502^{* * *}$ & $-0.653^{\text {档 }}$ & $-0.598^{* * *}$ & -0.494 *** & -0.057 \\
\hline $\begin{array}{l}\text { Mast cells in } \\
\text { jejunum }\end{array}$ & $-0.636^{* * *}$ & -0.519 档 & $-0.448^{* * * *}$ & $-0.420^{*}$ & 0.119 \\
\hline $\begin{array}{l}\text { Globule leucocytes } \\
\text { in duodenum }\end{array}$ & -0.301 & -0.325 & -0.280 & $-0.347^{*}$ & 0.031 \\
\hline $\begin{array}{l}\text { Globule leucocytes } \\
\text { in jejunum }\end{array}$ & $-0.711^{\text {橉 }}$ & -0.542 粠 & $-0.509^{* * *}$ & $-0.535^{* * *}$ & -0.049 \\
\hline $\begin{array}{c}\text { Eosinophils in } \\
\text { duodenum }\end{array}$ & $-0.384^{*}$ & $-0.342^{*}$ & -0.205 & -0.209 & -0.011 \\
\hline $\begin{array}{l}\text { Eosinophils in } \\
\text { jejunum }\end{array}$ & 0.038 & -0.094 & -0.079 & -0.029 & -0.100 \\
\hline
\end{tabular}

jejunum

a Spearman's rank correlation coefficients, b Fecal egg counts, c Daily production of eggs per female, ${ }^{*} \mathrm{P}<0.05$, ${ }^{*} \mathrm{P}<0.01$.

among mast cell, globule leucocyte, and eosinophil numbers in the duodenum and jejunum correlated positively (Table 1).

The correlation coefficients among the T. colubriformis worm burden, FEC, and male and female lengths were positive and statistically significant (Table 2).

Correlation coefficients between cell counts and T. colubriformis variables are shown in Table 3. Significant negative correlation coefficients were found between mast cells and Trichostrongylus worm burden, FEC and worm length. Similarly, all correlation coefficients between globule leucocyte counts versus Trichostrongylus variables were negative, but not all of them were statistically significant (Table 3).
Regarding eosinophils, significant negative correlation coefficients occurred between these cells in the duodenum and worm burden and FEC (Table 3).

\section{DISCUSSION AND CONCLUSIONS}

Previous work on these animals (Amarante et al. 2004) has shown that the Santa Ines sheep were more resistant to natural Haemonchus contortus, Cooperia curticei, and Oesophagostomum columbianum infections than Suffolk and Ile de France lambs, but no difference was found in resistance to Trichostrongylus colubriformis.

The three sheep breeds showed similar cellular responses in the small intestine mucosa. Santa Ines and Ile de France lambs infected artificially with $H$. contortus had more inflammatory cells in the abomasal mucosa than uninfected control sheep (Bricarello et al. 2005). However, as in the present experiment, Bricarello et al. (2005) did not detect significant differences among the breeds.

There was extensive variation among sheep in the parasitological and inflammatory cell variables, even among lambs of the same breed. In general, animals with less inflammatory cells had a larger worm burden, higher FEC, and larger $T$. colubriformis specimens. In Romney sheep breeding lines selected for low or high FEC, Bisset et al. (1996) found significantly higher numbers of globule leucocytes/mucosal mast cells in the intestinal mucosa in resistant than in susceptible lambs that were naturally infected with gastrointestinal nematodes. The overall Spearman rank correlation coefficient between globule leucocytes/mucosal mast cells versus T. colubriformis worm burden was -0.60 , while between eosinophils versus $T$. colubriformis it was -0.38 (Bisset et al. 1996), values similar to those found in the present study.

In the present experiment, the females produced an average number of less than 400 eggs/day. Dobson et al. (1990) reported that $T$. colubriformis fecundity in sheep remained high (about 600 eggs/day) for five weeks at the low infection rate, but only maintained this level for three weeks and one week at the medium and high rates, respectively. They suggested that fecundity, like establishment, was similarly affected at immunological recognition threshold levels. According to Dobson et al. (1990) density-dependent effects (parasite competition/crowding) could cause a decline in fecundity when worm population surpassed 3000 , which was the case for several animals in the present study, which had more than 
3000 T. colubriformis worms. However, there was no association between total burden $\mathrm{x}$ eggs/female $(r=-0.068)$.

The most susceptible animals, with bigger worm burdens, had longer male and female T. colubriformis adult worms. In agreement with this, Gruner et al. (2003) found that $H$. contortus female worms were shorter and had fewer eggs in utero in the F1 (more resistant) than in the INRA 401 lambs (more susceptible animals). Similarly, Stear et al. (1995) and Strain \& Stear (2001) showed that resistant sheep presented smaller-sized Ostertagia circumcincta and $H$. contortus worms, which were less fecund than worms found in susceptible sheep.

Rejection of incoming T. colubriformis larvae by immune sheep is accompanied by an intestinal inflammatory response involving secretion of biogenic amines into the duodenum and a concurrent plasma loss (Steel et al. 1990). However, in the present study, histamine concentration, measured in intestinal tissue samples, was not significantly associated with the parasitological variables. Similarly, in a herd of young grazing sheep, blood histamine levels and intestinal content fluid were similar in sheep with high and low egg counts and higher during maximum challenge by larval nematodes of several species (Douch et al. 1984). According to Jones et al. (1990), duodenal tissue histamine concentrations in lambs bred selectively for high responsiveness or low responsiveness to vaccination with irradiated T. colubriforimis were lower at 3 days than at 28 days post challenge. At 3 days post challenge, histamine concentration was higher in high responder lambs than in low responder lambs. Jones et al. (1990) found a significant negative correlation coefficient $(r=-0.46 ; P<0.05)$ between tissue histamine concentration and FEC at 28 days post challenge, while coefficients between histamine levels and EPG 21 days post challenge and worm counts $(-0.35$ and 0.28 , respectively) did not reach significant levels. In the present study, these coefficients between histamine $\mathrm{x}$ worm burden $(r=-0.164)$ and histamine x FEC $(r=-0.300)$ were also negative and not significant.

Histamine concentration in the small intestines was significantly correlated with mast cell numbers in the duodenum and jejunum $(P<0.01)$. Most of the overall correlation coefficients among mast cell, globule leucocyte, and eosinophil counts in the duodenum and jejunum were also positively correlated. These results indicate that animals with a high number of a certain cell type tend to also show a high number of the other cells. As mast cells produce histamine and give origin to globule leucocytes (Huntley et al. 1984, Balic et al. 2000), the association among these three variables was expected. In a group of 28-week-old pasture reared Merino sheep, Rothwell et al. (1993) also found that eosinophil counts in the intestine were positively correlated with mast cell counts $(r=0.534)$.

Excepting the Suffolk sheep, which had a significantly higher globule leucocyte mean in the duodenum than in the jejunum, similar numbers of mast cells, globule leucocytes and eosinophils were recorded at both sites. Samples were taken from the initial $1.1 \mathrm{~m}$ of the small intestine (in the duodenum at $10 \mathrm{~cm}$ from pylorum, and in the jejunum $110 \mathrm{~cm}$ from pylorum). According to Wagland et al. (1996) immunity to T. colubriformis is generated principally in the anterior $3 \mathrm{~m}$ of the small intestine, the site of predilection for parasite establishment. Bendixsen et al. (1995) reported similar results: mucosal mast cells isolated from the duodenum and mid-small intestines of immune sheep released 2-3 times more mast cell protease than cells recovered from the terminal ileum. Mast cell numbers were similar in the 3 regions, but the amount of globule leucocytes was 2.5 times higher in the duodenum (Bendixsen et al. 1995).

The inverse relationship between cell counts and worm burden, FEC and worm lengths proved that the most resistant animals of the three breeds of sheep had more inflammatory cells (mast cells, globule leucocytes, and eosinophils) in the intestinal mucosa. These cells possibly impaired parasite establishment, development, and survival.

Acknowledgements.- The author is grateful to Lucilene P. Mazzolin and Dr. José Carlos Gomes for the determination of histamine concentrations, and to Valdir A. Paniguel and Maria Angela B. Gomes for the valuable help in the experimental activities. This study was supported by the Fundação de Amparo à Pesquisa do Estado de São Paulo.

\section{REFERENCES}

Amarante A.F.T., Bricarello P.A., Rocha R.A. \& Gennari S.M. 2004. Resistance of Santa Ines, Suffolk and Ile de France sheep to naturally acquired gastrointestinal nematode infections. Vet. Parasitol. 120:91-106.

Balic A., Bowles V.M. \& Meeusen E.N.T. 2000. The immunobiology of gastrointestinal nematode infections in ruminants. Adv. Parasitol. 45:181-241.

Bendixsen T., Emery D.L. \& Jones W.O. 1995. The sensitization of mucosal mast cells during infections with Trichostrongylus colubriformis or Haemonchus contortus in sheep. Int. J. Parasitol. 25:741-748.

Bisset S.A., Vlassof A., Douch P.G.C., Jonas W.E., West C.J. \& Green R.S. 1996. Nematode burdens and immunological responses following natural challenge in Romney lambs selectively bred for low or high faecal worm egg count. Vet. Parasitol. 61:249-263.

Bricarello P.A., Amarante A.F.T., Rocha R.A., Cabral Filho S.L., Huntley J.F., Houdijk J.G.M., Abdalla A.L. \& Gennari S.M. 2005. Influence of dietary protein supply on resistance to experimental artificial infections with Haemonchus contortus in Ile de France and Santa Ines lambs. Vet. Parasitol. 134:99-109.

Dobson R.J., Waller P.J. \& Donald A.D. 1990. Population dynamics of Trichostrongylus colubriformis in sheep: the effect of infection rate on the establishment of infective larvae and parasite fecundity. Int. J. Parasitol. 20:347-352.

Douch P.G.C. 1989. The effects of immunization of sheep with Trichostrongylus colubriformis larvae on worm burdens acquired during grazing. Int. J. Parasitol. 19:177-181.

Douch P.G.C., Harrison G.B.L., Buchanan L.L. \& Brunsdon R.V. 1984. Relationship of histamine in tissues and antiparasitic substances in gastrointestinal mucus to the development of resistance to trichostrongyle infections in young sheep. Vet. Parasitol. 16:273-278.

Douch P.G.C., Harrison G.B.L., Elliott D.C., Buchanan L.L. \& Greer K.S. 1986. Relationship of gastrointestinal histology and mucus antiparasite activity with the development of resistance to trichostrongyle infections in sheep. Vet. Parasitol. 20:315-331.

Gill H.S., Altmann K., Cross M.L. \& Husband A.J. 2000. Induction of T helper 1- and $\mathrm{T}$ helper 2-type immune responses during Haemonchus contortus infection in sheep. Immunology 99:458-463.

Gruner L., Aumont G., Getachew T., Brunel J.C., Pery C., Cognié Y. \& Guérin Y. 2003. Experimental infection of Black Belly and INRA 401 straight and crossbred sheep with trichostrongyle nematode parasites. Vet. Parasitol. 116:239-249. 
Jones W.O., Windon R.G., Steel J.W. \& Outteridge P.M. 1990. Histamine and leukotriene concentrations in duodenal tissue and mucus of lambs selected for high and low responsiveness to vaccination and challenge with Trichostrongylus colubriformis. Int. J. Parasitol. 20:1075-1079.

Keith R.K. 1953. The differentiation of infective larvae of some common nematode parasites of cattle. Aust. J. Zool. 1:223-235.

Harrison G.B.L., Pulford H.D., Gatehouse T.K., Shaw R.J., Pfeffer A. \& Shoemaker C.B. 1999. Studies on the role of mucus and mucosal hypersensitivity reactions during rejection of Trichostrongylus colubriformis from the intestine of immune sheep using an experimental challenge model. Int. J. Parasitol. 29:459-468

Huntley J.F., Newlands G. \& Miller H.R.P. 1984. The isolation and characterization of globule leucocytes: their derivation from mucosal mast cells in parasitized sheep. Parasite Immunol. 6:371-390.

Ott R.L. 1992. An Introduction to Statistical Methods and Data Analysis. 4th ed. Wadsworth Publishing Company, Belmont. 1051p.

Rothwell T.L.W., Windon R.G., Horsburgh B.A. \& Anderson B.H. 1993. Relationship between eosinophilia and responsiveness to infection with Trichostrongylus colubriformis in sheep. Int. J. Parasitol. 23:203-211.

Shore P.A., Burkhalter A. \& Cohn V.H. 1959. A method for the fluorometric assay of histamine in tissues. J. Pharmacol. Exp. Ther. 127:182-186.
Stear M.J. \& Murray M. 1994. Genetic resistance to parasitic disease: particularly of resistance in ruminants to gastrointestinal nematodes. Vet. Parasitol. 54:161-176.

Stear M.J., Bishop S.C., Doligalska M., Duncan J.L., Holmes P.H., Irvine J., McCririe L., McKellar Q.A., Sinski E. \& Murray M. 1995. Regulation of egg production, worm burden, worm length and worm fecundity by host response in sheep infected with Ostertagia circumcincta. Parasite Immunol. 17:643-652.

Strain S.A.J. \& Stear M.J. 2001. The influence of protein supplementation on the immune response to Haemonchus contortus. Parasite Immunol. 23:527-531.

Steel J.W., Jones W.O. \& Wagland B.M. 1990. The response of immune sheep to challenge with Trichostrongylus colubriformis: enteric plasma loss and secretion of biogenic amines. Int. J. Parasitol. 20:1067-1073.

Ueno H. \& Gonçalves P.C. 1998. Manual para diagnóstico das helmintoses de ruminantes. $4^{\mathrm{a}}$ ed. Japan International Cooperation Agency, Tokyo. 143p.

Wagland B.M., Emery D.L. \& McClure S.J. 1996. Studies on the host-parasite relationship between Trichostrongylus colubriformis and susceptible and resistant sheep. Int. J. Parasitol. 26:1279-1286.

Winter M.D., Wright C. \& Lee D.L. 1997. The mast cell and eosinophil response of young lambs to a primary infection with Nematodirus battus. Parasitology 114:189-193. 